\title{
Ervand Abrahamian, A History of Modern Iran
}

(Cambridge: Cambridge University Press, 2008), xxv+228 pp.

ISBN: $9780521528917 . £ 10.80$

\section{Christoph Marcinkowski International Institute of Advanced Islamic Studies (IAIS) Malaysia}

Ervand Abrahamian, the author of this well-written book and a member of Iran's ethnic Armenian minority, is Distinguished Professor of History at Baruch College and Graduate Center of City University of New York. His previous publications, among them The Iranian Mojahedin (1989), Khomeinism (1993) and Tortured Confessions (1999), feature more or less the left-wing political perspective of their author - especially in terms of socio-political and socio-economic analysis.

Another reviewer - Edward Mortimer, Senior Vice-President of the Salzburg Global Seminar - pointedly stated that "Ervand Abrahamian has done for Iran what de Tocqueville did for France, showing how the revolution continued the work of the ancien régime through the ever increasing power of the state." In addition to this, other scholars in Iranian Studies, among them this reviewer who lived in Iran for several years during the $1980 \mathrm{~s},{ }^{1}$ have also argued that Iran's foreign policy under the post-1979 regime, too, shows remarkable signs of continuity (rather than a break) with the previous Pahlavi era. In true Marxist analysis - but in the case of Iran's history since the late Qajar era - actually based on historical facts rather than myths, Abrahamian argues throughout his book - as its main thesis - that the history of Iran since the late 1800 s is actually the history of the growth of the state. The late Qajar period - the Pahlavi years - the current regime... all of them building on the policies of their predecessor, even if day-to-day political announcements and propaganda directed at the masses might suggest the contrary.

Iran at the beginning of the twenty-first century thus emerges as one of the most powerful states in the Middle East. As this writer has argued elsewhere, ${ }^{2}$ this regional pre-eminence of Iran is not the result of any chimerical Iran-sponsored 'Shi' ite Crescent', heralding the 'fall' of Shi' ite-dominated or majority countries like Lebanon, Bahrain, or Iraq to a supposed remote-controlling regime in Tehran, but rather based on purely altruistic national Iranian self-interest. The historically informed observer will therefore notice an unbroken development: from the pre-Islamic Sassanid period and its conflict with Rome - the Western 'superpower' of those days - over the Safavid period (from the sixteenth to eighteenth century) which brought about this link between Iranian nationalism and Shi'ism that is often thought to be the characteristic hallmark of Iranian identity, to the Pahlavi regime which despite its dependence on the West was actually aiming at regional domination, to finally the regime of an 'Islamic republic' under Khomeini and now 
Ahmadinejad. The latter two merely used, mobilised and instrumentalised Shi'ite sentiments, anti-Western sensitivities among Sunnites, along with 'converts' to Shi'ism, throughout the Middle East and beyond, to further the national rather than religious interests of their home country - Iran. How deep national interest is currently determining Iranian foreign policy became clear also to a wider audience in Iran's support of (Christian) Armenia in its epic conflict with (Shi'ite) Azerbaijan in the early 1990s (a support which continues to this day), or, long before that, in the so-called 'Iran-Contra Affair' and Tehran's secret arms dealing with supposed archenemy Israel and the United States while the Ayatollah's child soldiers were bleeding to death in their fight against Saddam Hussein's Iraq. Policy-makers in the West would therefore be well-advised to see in Iran's resurgence the superpower pretensions of a regional power.

Abrahamian's book is an eye-opener and reads like a thriller - without featuring the often lengthy and boring lecturing of several of his other left-wing colleagues among the analysts. It shows how - since the late Qajar era, over the Pahlavis, to the current regime - the power of the central government in Tehran has grown rather than diminished. This growth of central authority has led to higher tax revenue and, subsequently, to drastic increases in military expenditure and internal structural development. The current high level of development would have been impossible without reference to the roots that had been planted in the Pahlavi era. Abrahamian, therefore, is also right when he considers the 1978/79 revolution not as the result of some sort of religious sentiment, but rather the outcome of failed socio-economic policies - a revolution in which several (and quite dissimilar and at times antipodal) segments of Iranian society took part, but which was merely 'high-jacked' by the Shi'ite clerics.

There are, however, also some shortcomings for which the editor in particular seems to be responsible and which could have been easily avoided. For example it seems reasonable to suggest that, for a book aimed beyond Iranicists, it is unacceptable from an editorial point of view (not to speak from that of professionalism) that a reputable publisher like Cambridge University Press has apparently left almost untouched the author's haphazard and inconsistent (and often even unintelligible) style of transliteration. On the other hand, the volume contains also several very telling illustrations - postal stamps from the Pahlavi and post-1979 periods - which demonstrate further the prevalent policies of the time.

In sum then, specialist and general readers alike - together with, hopefully, policy-makers in the West - will certainly profit greatly from this slim but meaty volume as this authoritative overview of twentieth-century Iran fills a gap in the literature of Iranian Studies and as it opens new vistas and avenues for addressing the question of Iran's future. 


\section{Notes}

1. Christoph Marcinkowski, Shi'ite Identities: Community and Culture in Changing Social Contexts, Freiburg Studies in Social Anthropology 27 (Vienna: LIT Verlag, 2010), 82-3.

2. Ibid., 81-2, 95 .

\section{P. Lim Pui Huen, Johor: Local Histories, Local Landscapes, 1855-1957 \\ (Singapore: Straits Times Press, 2009), 240 pp. ISBN: 9789814266260. SG\$55.00}

\section{Christoph Marcinkowski International Institute of Advanced Islamic Studies (IAIS) Malaysia}

On 15 July 2010, IAIS Malaysia hosted a public seminar on "The Impact of Globalisation on Contemporary Muslim Societies", which was attended by more than 300 guests, among them foreign diplomats and academics. The highlight of this event, however, was the Royal Address by HRH Raja Zarith Sofiah binti Almarhum Sultan Idris Shah II, the consort of the Sultan of Johor. In her speech, entitled "Globalisation: Building Bridges Between Islam and the West", HRH Raja Zarith Sofiah pointed out that mutual understanding is also important if Muslims are to rid themselves of their stereotypical image as terrorists and extremists, whereas Muslims must know that they share a common history with people of other faiths. Elsewhere, this reviewer, too, has been trying to emphasise the important role played by Malaysia's monarchy within the context of the contemporary discourse on extremism. ${ }^{1}$ As a matter of fact, Malaysia's system of constitutional monarchy has always understood itself - and indeed functioned - as a mediator and a bridge.

Johor Darul Ta'zim - the 'Abode of Dignity' - and its Sultans had always been such a bridge between civilisations. Johor is also one of those Malaysian states that are still marked by mutual respect between the races and mutual love between the royal family and their subjects. ${ }^{2}$ One of the heroes of Johor's more recent history, HRH Sultan Abu Bakr, the great moderniser, is also fondly known as the 'Father of Modern Johor', as many historians accredited Johor's development in the nineteenth century to his enlightened leadership. He initiated policies and provided aids to ethnic Chinese entrepreneurs to stimulate the development of the state's agricultural economy which was founded by Chinese migrants from Southern China in the 1840s. He also took charge of the development of Johor's infrastructure, administrative system, and military and civil service, all of which were modelled closely along Western lines. Sultan Abu Bakar was also noted for his diplomatic skills, and both the British and Malay rulers had approached him for advice in making important decisions. He was also an avid traveller and became 